\title{
GROŽIO TERAPIJOS PASLAUGŲ SEKTORINIAME PRAKTINIO MOKYMO CENTRE KOKYBĖS VERTINIMAS
}

\author{
Jūratė Jocienė, Nijolè Deksnienė, Alicija Ramanauskaitė \\ Šv. Ignaco Lojolos kolegija
}

\begin{abstract}
Anotacija
Straipsnyje analizuojami grožio terapijos paslaugų sektoriniame praktinio mokymo centre kokybės vertinimo praktiniai aspektai, apibūdinama grožio terapijos paslaugos kokybè ir jos kriterijai, pristatomi grožio terapijos paslaugų kokybès tyrimo vartotojų požiūriu rezultatai. Straipsnis parengtas, remiantis mokslinès ir normatyvinès literatūros analize, autorių atlikto kokybès tyrimo rezultatais, kurie grindžiami grožio terapijos paslaugų kokybės vertinimo modeliu.

PAGRINDINIAI ŽODŽIAI: kokybė, grožio terapijos paslaugos, vartotojų požiūris, sektorinis praktinio mokymo centras.
\end{abstract}

\begin{abstract}
The article analyzes the practical aspects of quality evaluation of beauty therapy services quality at the thepractical teaching center and describes the beauty therapy service quality and its criteria of introdusing quality test results from perspective of a consumer This article is based on the analysis of scientific and normativeliterature and the results of quality research which are based on the model of beauty therapy service quality evaluation.

KEY WORDS: Quality, Beauty Therapy service, consumer point of view, sectoral practical training center.
\end{abstract}

DOI: http://dx.doi.org/10.15181/tbb.v76i1.1518

\section{Ivadas}

Vienas pagrindinių iššūkių grožio terapijos paslaugų sektoriui yra paslaugų kokybė, kaip labiausiai vartotojų vertinamas aspektas. Šiuo metu grožio terapijos paslaugų rinka išgyvena pakilimą šios augimo tendencijos yra pastovios ${ }^{1}$. Statistikos departamento duomenimis, grožio paslaugas teikiančių įmonių darbuotojų skaičius ir pajamos Lietuvoje per pastaruosius kelerius metus nuolat augo. Didèjant šių paslaugų pasiūlai, grožio terapijos paslaugų kokybẻ tampa vienu svarbiausių kriterijų rinkoje. Pasak A. Lopaciuk ir M. Loboda (2013), vis didesnis dèmesys skiriamas grožio terapijos produktų ir teikiamų paslaugų kokybei.

Paslaugų kokybės tyrimai grožio terapijos praktinėje veikloje tampa būtinybe, nes tik kokybiškos paslaugos lemia vartotojų pasitenkinimą. Kokybė formuoja grožio terapijos paslaugų ịmonès įvaizdį, daro įtaką vartotojų pasitenkinimui, ska-

\footnotetext{
Beauty and Personal Care Products Industry Overview [interaktyvus]. Prieiga internete: https://www. business.com/articles/beauty-and-personal-care-products-industry-overview/ [žiūrèta 2016-04-25]; Beauty $\&$ Personal Care Trends [interaktyvus]. Prieiga internete: http://www.mintel.com/beauty-and-personal-caretrends/ [žiūrèta 2016-04-25].
} 
tina vartotojų lojalumą, verslo plètrą, didesnį darbuotojų efektyvumą, kuria geresnę reputaciją (Vitkienè, 2004).

Paslaugų kokybės vertinimas yra sudètingas procesas, nes paslaugos yra heterogeninès, neatskiriamos ir naudojamos jų teikimo metu (Bagdonienè, Hopeniené, 2005). Būtent dẻl šių savybių nustatyti grožio terapijos paslaugų kokybę sudètinga.

Vartotojų laisvė rinktis ilgą laiką buvo vienintelè paskata siekti grožio terapijos paslaugų teikimo kokybės. Nagrinėjant grožio terapijos paslaugų kokybės temą sudètinga remtis ịprastais kokybès vadybos principais, todèl svarbu atsižvelgti ị vartotojų požiūrị. Lietuvoje grožio terapijos paslaugų sektoriaus kokybẻ pastaraisiais metais tyrinèta, tačiau ši tema toli gražu dar neišsemta. Juolab kad grožio terapijos paslaugų sektorius yra sparčiai besivystantis, nuolat kintantis, jautriai reaguojantis ị permainas. İ grožio terapijos paslaugų rinką žengia nauji dalyviai - sektoriniai praktinio mokymo centrai ${ }^{2}$, kurie naudojami kaip studentų praktikos ịmonès, todèl grožio terapijos paslaugų kokybės tyrimas šiuose centruose aktualus, siekiant, kad studentų praktika būtų kokybiška.

Tyrimo objektas - grožio terapijos paslaugų kokybè.

Tyrimo problema: iki šiol sektoriniame praktinio mokymo centre grožio terapijos paslaugų kokybė vartotojų požiūriu netirta.

Tyrimo tikslas: įvertinti grožio terapijos paslaugų kokybę pasirinktame sektoriniame praktinio mokymo centre vartotojų požiūriu.

Tyrimo tikslui pasiekti išsikelti šie uždaviniai:

1. Aptarti grožio terapijos paslaugos kokybès sampratą.

2. Apibūdinti grožio terapijos paslaugos kokybès vertinimo kriterijus.

3. Išsiaiškinti, kaip vartotojai vertina grožio terapijos paslaugų kokybę praktinio mokymo centre.

Tyrimo metodika. Teorinis požiūris grindžiamas mokslinès literatūros ir norminių dokumentų analize. Tiriant ir analizuojant grožio terapijos paslaugų kokybės tendencijas taikomi šie tyrimo metodai: mokslinès literatūros šaltiniuose paskelbtų koncepcijų ir išvadų sisteminè bei lyginamoji analizè. Grožio terapijos paslaugų vartotojų pasitenkinimui paslaugų kokybe nustatyti atliktas kiekybinis tyrimas.

\section{Grožio terapijos paslaugos kokybės samprata}

Grožio terapijos samprata paaiškinta J. C. Segen (2012) Medicinos žodyne - tai yra grožio terapijos priežiūros priemonių, pvz., veido odos priežiūros, manikiūro,

Sektorinis praktinio mokymo centras - tai modernia praktinio mokymo įranga aprūpinta profesinio mokymo įstaiga arba jos savarankiškas padalinys, susijęs su vienu ar keliais Lietuvos ūkio sektoriais (Sektorinių praktinio mokymo centrų plètros programa, patvirtinta LR ŠMM 2008 m. gegužès 22 d. ịsakymu Nr. ISAK-1463). 
pedikiūro, depiliacijos ir kt., taikymas, siekiant pagerinti asmens fizinę išvaizdą. Pasak J. Jocienės (2010), grožio terapijos specialistas gali būti apibūdintas kaip grožio terapeutas, higieninès ir dekoratyvinès kosmetikos technologas, kuris naudoja ịvairias priemones ir būdus, kad pagerintų žmogaus išvaizdą. Grožio terapijos specialistų pagrindinè veiklos forma - paslaugų teikimas.

Paslauga apima kelių veiksmų seką, kur sąveikauja teikejas ir vartotojas. Šis procesas dar papildomas materialiomis priemonemis (ịranga, medžiagomis). V. Langvinienè, B. Vengrienè (2005), E. Vitkienè (2008) skirtingai apibrěžia paslaugos sampratą. Pasak V. Langvinienès ir B. Vengrienès (2005), paslauga yra savitas teikèjo ir gavejjo bendradarbiavimas, tenkinant gavejjo poreikius. Paslaugu paskirtis - tenkinti poreikius, nebūtinai suteikiant apčiuopiamą rezultatą, sukuriant materialų produktą. Paslauga ịvardijama kaip žmonių bendradarbiavimo rezultatas. E. Vitkienė (2008) paslaugą apibrèžia kaip neapčiuopiamą veiklą, paprastai pasireiškiančią vartotojui sąveikaujant su paslaugos teikèjais, materialiaisiais ištekliais, prekėmis arba teikimo sistemomis, ji užtikrina, kad vartotojo problema bus išspręsta. Suteiktos paslaugos dalimi tampa ne tik techninis problemos sprendimas, bet ir santykiai teikiant paslaugą - vartotojas bendrauja su paslaugų teikejjais.

Grožio terapijos paslaugos samprata. Teisès aktuose grožio terapijos paslaugos apibrèžimo nepavyko surasti. Grožio paslaugos apibrèžtos ir atsižvelgiant ị riziką sveikatai suskirstytos ị A ir B kategorijos paslaugas (Higienos norma HN 117:2007, 2007). Darbo autorių nuomone, iš grožio paslaugų sąrašo atskyrus plaukų priežiūros paslaugas, kitas galètume priskirti grožio terapijos paslaugoms. Iš esmès tai veido ir kūno priežiūros paslaugos.

Remiantis E. Vitkienès (2008), V. Langvinienès ir B. Vengrienès (2005) išvadomis, grožio terapijos paslauga turi visas klasikinių paslaugų savybes: ji yra heterogeninè (vienam vartotojui nėra visiškai tokia pati kaip kitam), neapčiuopiama (nemateriali, nekaupiama, negali tapti nuosavybe), atitinka neatskiriamumo kriterijų (teikimas ir vartojimas vyksta tuo pačiu metu), pagrindinis paslaugos vartotojas suaugęs žmogus, dalyvaujantis paslaugos teikimo procese.

Grožio terapijos paslaugos kokybè. Siekiant grožio terapijos kokybès, reikia įvertinti šios srities specifiškumą. Pritaikius bendruosius paslaugos kokybės reikalavimus, galima teigti, kad grožio terapijos paslaugos kokybe - tai grožio terapijos paslaugos savybių visuma, galinti patenkinti vartotojo poreikius. Išmatuoti grožio terapijos paslaugos kokybę sudètinga, nes pati paslauga yra kompleksinė.

Mokslininkai skiria techninę ir funkcinę paslaugų kokybes (Vitkiené, 2004; Langvinienè, Vengrienè, 2005; Bagdonienè, Hopenienè, 2009). Pasak E. Vitkienès (2004), paslaugų kokybė suvokiama subjektyviai, nes paslauga teikiama ir vartojama vienu metu. Šiame procese paslaugų vartotojai ir teikẻjai sąveikauja, tai lemia vartotojo paslaugos kokybės suvokimą. Grožio terapijos paslaugos techni- 
nẻ kokybė gali būti apibrèžiama kaip atitikimas iš anksto nustatytiems parametrams, kurie pateikiami paslaugos aprašymuose, technologiniuose reikalavimuose ar standartuose. Bet koks nukrypimas nuo standarto traktuojamas kaip neatitiktis. Techninè grožio terapijos paslaugos kokybė vertinama objektyviai, paslaugos charakteristikos turi atitikti standartus, o pati paslauga turi būti veiksmingai teikiama priimtinomis kainomis. Tuo tarpu funkcinė kokybė įgauna neapčiuopiamumo pobūdị: ji apima tokias paslaugos teikimo proceso charakteristikas kaip darbuotojų kompetencija, požiūris, elgesys, darbo kultūra. Funkcinė kokybė negali būti objektyviai ịvertinta. Funkcinė grožio terapijos paslaugos kokybė apima tokias proceso charakteristikas kaip aptarnavimo lygis, vertybinès nuostatos, darbuotojų požiūris, jų kompetencija, komunikacinè elgsena.

Kokybė vartotojo požiūriu sunkiai nustatoma dèl skirtingų vartotojų skonio ir poreikių. Tačiau tik vartotojas yra tikrasis kokybės vertintojas, todèl vertinant grožio terapijos paslaugas reikètų vadovautis jo požiūriu. Vartotojų požiūriu, grožio terapijos paslaugų teikimo kokybės svarbiausias veiksnys yra specialistai - grožio terapeutai, nes jie tampa galutiniais paslaugų išskirtinumo reguliuotojais. Pasak J. Jocienès ir bendraautorių (2014), didžiausią ịtaką paslaugos kokybei daro darbuotojų profesionalumas, ịgūdžiai, kompetencija, gebẻjimas sudaryti gerą ịspūdị, požiūris ir elgesys. Ittakos turi ir materialieji ištekliai: patalpos, darbo priemonès ir ịranga, medžiagos, komunikacijos priemonès (interneto ryšys, el. paštas, telefonas ir kt.). Prie šių išteklių priskiriami ir finansiniai ištekliai.

Grožio terapijos paslaugas teikiančių ịmonių uždavinys - ne tik plètoti ir tobulinti paslaugų žmogiškuosius ir materialiuosius išteklius, bet ir teikti saugias sveikatai paslaugas. Grožio terapijos paslaugų saugumas - svarbi kokybės dimensija. Grožio terapijos paslaugas teikiančių ịmonių paslaugų reikalavimus numato Lietuvos Respublikos sveikatos apsaugos ministro įsakymu patvirtintos Lietuvos higienos normos HN 117:2007 „Grožio paslaugų sveikatos saugos reikalavimai“ (2007).

Vartotojų vaidmuo. Grožio terapijos paslaugų kokybẻ negali būti atskirta nuo vartotojų pasitenkinimo. Kokybiškos paslaugos - tai paslaugos, kurios ne tik atitinka standartus, nustatytus kriterijus, bet pirmiausiai yra priimtinos vartotojams, atitinka jų reikalavimus. Būtent vartotojas yra pagrindinis kokybès arbitras (Langvinienè, Vengrienè, 2005, p. 74). Todèl grožio terapijos paslaugu kokybė gali būti išreiškiama pasitenkinimu, kuri iš tos paslaugos gauna vartotojas. Kuo labiau vartotojas patenkintas, tuo geresnè paslaugos kokybė. Laikoma, kad grožio terapijos paslauga suteikta kokybiškai, jei darbo rezultatais ar paslauga vartotojas yra patenkintas. Jei suteikta grožio terapijos paslauga gerokai viršija vartotojų lūkesčius, galima teigti, kad ji - išskirtinès kokybès. 
Tyrimai, apklausos, socialinių tinklų surinkta informacija, lojalumo kortelès ir kiti šaltiniai leidžia grožio terapijos paslaugų industrijai pažinti savo vartotojus. Populiariausias būdas - pasitenkinimo apklausos, periodiškai vykdomos tam tikrais laiko tarpais ir leidžiančios pastebèti pokyčius. Vartotojų pasitenkinimu galima paaiškinti grožio terapijos įmonių sèkmę - pelnas auga kasmet, rinka plečiasi, vartojimo tempai dideja (Global Beauty Care Products Industry, 2012).

Kokybès vertinimas. Mokslinèje literatūroje (Bagdonienè, Hopenienè, 2004; Vitkienè, 2004; Langvinienè, Vengrienè, 2005; Palaima, 2005) pateikiama nemažai skirtingų paslaugų kokybės vertinimo modelių.

P. Parasuraman, V. A. Zeithaml ir L. L. Berry sukūrè kokybès spragų modelị (1988), kurị E. Vitkienè (2004) pavadino klaidų analizės modeliu. Pagal ši modelị kokybę formuoja du subjektai - vartotojas ir paslaugos teikejjas. Vadovaujantis kokybės spragų modeliu galima teigti, kad spraga yra atotrūkis tarp vartotojų lūkesčių ir pasitenkinimo suteiktomis paslaugomis.

Europos vartotojų pasitenkinimo valdymo vadove (2010) teigiama, kad patirtos paslaugos atitikimas vartotojų lūkesčiams leidžia ịvertinti paslaugos kokybę ir nustatyti pasitenkinimo lygị. Šị modelị galima pritaikyti grožio terapijos paslaugoms, nustatant kokybės spragas (1 pav.).

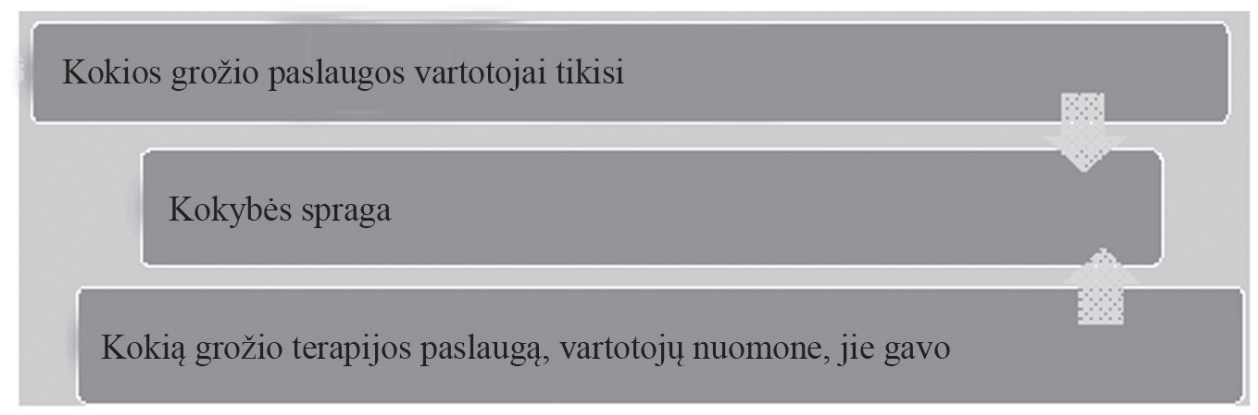

1 pav. Grožio terapijos paslaugos kokybės spragų modelis

Sudaryta remiantis: Europos vartotojų pasitenkinimo valdymo vadovas, 2010

Pritaikius ši modelį grožio terapijos paslaugu įmonei ir siekiant išvengti vartotojų nepasitenkinimo dèl jų lūkesčių atsiradimo bei tolesnio plètojimosi, reikia numatyti ir taikyti kokybès neatitikimo šalinimo priemones. Galimos kokybės spragos ir jų šalinimo priemonès grožio terapijos įmonẻje pateiktos 1 lentelèje. 
Jūratė Jocienè, Nijolè Deksnienè, Alicija Ramanauskaitė

1 lentele. Kokybės spragos grožio terapijos paslaugų įmonėje ir jų šalinimo priemonès

\begin{tabular}{|c|c|c|c|}
\hline $\begin{array}{l}\text { Eil. } \\
\text { Nr. }\end{array}$ & Kokybės spraga & Jos charakteristika & Spragos šalinimo priemonès \\
\hline 1. & $\begin{array}{l}\text { Vartotojų lūkesčių } \\
\text { ir grožio terapijos } \\
\text { paslaugos } \\
\text { teikejjo gebejimų } \\
\text { juos suvokti } \\
\text { neatitikimas }\end{array}$ & $\begin{array}{l}\text { Grožio terapijos paslaugos } \\
\text { teikėjas deramai nesuvokia } \\
\text { vartotojų lūkesčių. Grožio } \\
\text { terapijos specialistai ir gro- } \\
\text { žio terapijos įmonių vadovai } \\
\text { nesidomi ir nežino, kokios } \\
\text { paslaugos savybès atitinka } \\
\text { vartotojo poreikius ir kaip } \\
\text { paslauga turi būti pateikta, } \\
\text { norint šiuos poreikius pa- } \\
\text { tenkinti }\end{array}$ & $\begin{array}{l}\text { Komunikacijos gerinimas, siekiant } \\
\text { pažinti savo vartotojus; tiesioginis ben- } \\
\text { dravimas su vartotojais; vartotojų išklau- } \\
\text { symas ir išsiaiškinimas: } \\
\text { • ko jis tikisi iš grožio terapijos } \\
\text { paslaugos; } \\
\text { - kokie jo lūkesčiai ir poreikiai }\end{array}$ \\
\hline 2. & $\begin{array}{l}\text { Grožio terapijos } \\
\text { paslaugos teikèjo } \\
\text { suvokiamų var- } \\
\text { totojų lūkesčių ir } \\
\text { jų modifikavimo ì } \\
\text { paslaugos savybes } \\
\text { neatitikimas }\end{array}$ & $\begin{array}{l}\text { Iškyla pasiūlos ir paklausos } \\
\text { derinimo problema. Atsi- } \\
\text { randa neatitikimas tarp pa- } \\
\text { slaugos teikejjo ir vartotojų } \\
\text { suvokiamų paslaugos savy- } \\
\text { bių. Nėra kokybės politikos. } \\
\text { Neaprašyti arba netaikomi } \\
\text { kokybės kriterijai. Sumenki- } \\
\text { namas vartotojų požiūris }\end{array}$ & $\begin{array}{l}\text { - Kokybės kriterijų, atskleidžiančių } \\
\text { vartotojų lūkesčius, nustatymas. } \\
\text { - Aiškiai aprašytos paslaugos savybės, } \\
\text { atitinkančios vartotojų lūkesčius. } \\
\text { - Pozityvaus požiūrio į vartotoją } \\
\text { ugdymas. } \\
\text { - Vadovų ir darbuotojų kompetencijos } \\
\text { tobulinimas. } \\
\text { - Papildomas darbuotojų skatinimas } \\
\text { siekti kokybės }\end{array}$ \\
\hline 3. & $\begin{array}{l}\text { Grožio terapijos } \\
\text { paslaugos teikimo } \\
\text { nukrypimas nuo } \\
\text { nustatytų standartų }\end{array}$ & $\begin{array}{l}\text { Nepakankama kokybės } \\
\text { kontrolė; kokybės reikalavi- } \\
\text { mų nepaisymas, nepakanka- } \\
\text { ma specialistų kompetenci- } \\
\text { ja, nepalanki darbo atmos- } \\
\text { fera: ambicijos, konfliktai, } \\
\text { nepagrįsta konkurencija }\end{array}$ & $\begin{array}{l}\text { - Sisteminga kokybės kontrolè. } \\
\text { - Nustatytų standartų laikymasis. } \\
\text { - Palankių darbo sąlygų sudarymas. } \\
\text { - Kompetentingų darbuotojų } \\
\text { samdymas. } \\
\text { - Darbuotojų kompetencijų } \\
\text { tobulinimas. } \\
\text { - Komandinio darbo skatinimas. } \\
\text { - Darbuotojų nepagristos konkurencijos } \\
\text { netoleravimas }\end{array}$ \\
\hline 4. & $\begin{array}{l}\text { Grožio terapijos } \\
\text { paslaugos teikimo } \\
\text { ir reklamos } \\
\text { neatitikimas }\end{array}$ & $\begin{array}{l}\text { Grožio terapijos įmonė } \\
\text { negali žadėti daugiau, nei } \\
\text { yra pajėgi ištesėti. Reklama } \\
\text { ir komunikacinè elgsena } \\
\text { turi būti etiška, teisinga, } \\
\text { sąžininga. Vartotoją turi } \\
\text { pasiekti aiški ir tiksli } \\
\text { informacija apie paslaugas }\end{array}$ & $\begin{array}{l}\text { - Reklamos etikos laikymasis. } \\
\text { - Racionalūs pažadai ir jų laikymasis. } \\
\text { - Vidinės ir išorinès komunikacijos. } \\
\text { gerinimas. } \\
\text { - Informavimo šaltinių ịvairinimas. } \\
\text { - Vartotojų mokymas ir švietimas }\end{array}$ \\
\hline
\end{tabular}




\begin{tabular}{|c|c|c|c|}
\hline $\begin{array}{l}\text { Eil. } \\
\text { Nr. }\end{array}$ & Kokybės spraga & Jos charakteristika & Spragos šalinimo priemonės \\
\hline 5. & $\begin{array}{l}\text { Laukiamos ir } \\
\text { realiai patirtos } \\
\text { grožio terapijos } \\
\text { paslaugos kokybės } \\
\text { spragų mažinimas }\end{array}$ & $\begin{array}{l}\text { Vartotojai kokybę vertina } \\
\text { lūkesčius lygindami su } \\
\text { patirta paslauga. Kuo } \\
\text { mažesnè laukiamos ir } \\
\text { patirtos kokybės spraga, tuo } \\
\text { geriau vartotojas vertina } \\
\text { kokybę }\end{array}$ & $\begin{array}{l}\text { - Sistemingai vykdyti vartotojų } \\
\text { apklausas, siekiant nustatyti jų } \\
\text { lūkesčius ir patirtą kokybę. } \\
\text { - Grožio terapijos paslauga turi atitikti } \\
\text { arba viršyti vartotojo lūkesčius, } \\
\text { todėl tinka visos aukščiau minètos } \\
\text { priemonės }\end{array}$ \\
\hline
\end{tabular}

Šaltinis: Bagdonienè, 2004

Patenkinti vartotojų lūkesčiai lemia jų pasitenkinimą kokybe ir lojalumą. Vertinant grožio terapijos paslaugų kokybę gali būti taikomas priežasties ir pasekmès modelis, susiejantis vartotojų lūkesčius (priežasties elementas) su vartotojų lojalu$\mathrm{mu}$ (pasekmès elementas) (2 pav.).

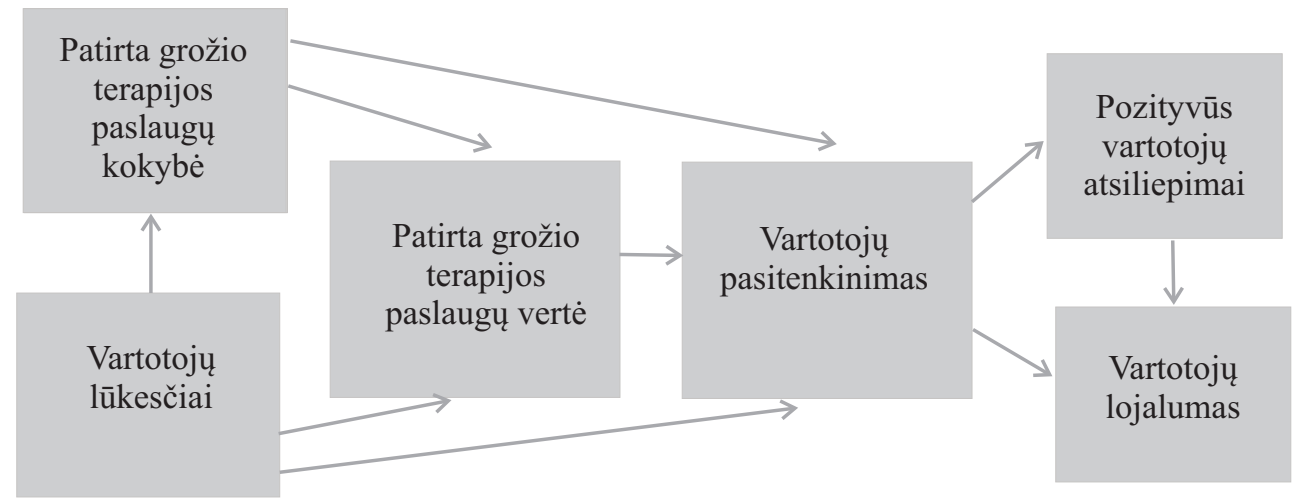

2 pav. Grožio terapijos paslaugų kokybės vertinimo modelis

Šis modelis atskleidžia, kokie veiksniai turi įtakos vartotojų lojalumui: vartotojų lūkesčiai, patirta grožio terapijos paslaugų kokybè, paslaugų vertè. Jeigu šie elementai suderinti, garantuojamas vartotojų pasitenkinimas ir geri atsiliepimai. Taip galima užsitikrinti, kad vartotojai pakartotinai grịžtu i grožio terapijos paslaugų įmonę, rekomenduotų ją artimiesiems, draugams ir pažịstamiems.

Vertybinès nuostatos. Vertybinès kokybès nuostatos ir kokybės kultūra yra ypač svarbūs teikiant grožio terapijos paslaugas. Grožio terapeutų teikiamos paslaugos nėra vien grožio terapijos procedūrų atlikimas pagal taisykles. Jie privalo sukurti sąlygas vartotojui pabūti malonioje aplinkoje, užmegzti teigiamą ir gana artimą, nors ir trumpalaikị, ryšĭ. Pasak V. Isiūnienès, G. Adomavičienès ir Ž. Mickienès (2012, p. 188), grožio terapeutas yra ir savo profesijos menininkas, siūlantis 
vartotojui ịvairius kūrybinius sprendimus. Todėl grožio terapijos paslaugų teikèjas turi ne tik teikti techninius reikalavimus atitinkančias paslaugas, bet ir savo veiklą grịsti atitinkamomis vertybemis.

Vertybinis aptarnavimo pagrindas susieja esmines grožio terapijos paslaugų i̇monès vertybes ir vartotojų aptarnavimo standartus. Vienas pagrindinių etinių reikalavimų - aukšta vartotojų aptarnavimo kultūra. Ji apima dėmesị ir pagarbą kiekvienam vartotojui. Šiandieninis aptarnavimas grožio terapijos paslaugų įmonèse turi būti lankstus ir empatiškas, vartotojų poreikiai tenkinami, atsižvelgiant ị individualias situacijas, suderinant interesus.

Viena pagrindinių vertybių - atsakomybė už atliktą darbą, įsipareigojimų vartotojams laikymasis. Didelis dèmesys turi būti skiriamas informacijos etikai ir aiškumui: teisingos informacijos apie grožio terapijos paslaugas teikimui ir atitikimui teikiamoms paslaugoms.

Siekiant orientuotis ị vertybinị pagrindą, atsiranda didesnè tikimybė, kad vartotojai pakartotinai naudosis paslaugomis, pirmenybę teiks tai grožio terapijos paslaugų įmonei, kuri labiausiai atitiks jų moralinius standartus ir patenkins jų poreikius. Skaidrios vertybinès nuostatos, aukšta kokybès kultūra sukuria prielaidas vartotojų lojalumui, geram grožio terapijos paslaugų ịmonès ịvaizdžiui.

Pasiekus aukštą vartotojų pasitenkinimo grožio terapijos ịmonèje lygị, galima orientuotis ị patraukliają kokybę (Kano, 1984). Remiantis N. Kanu, kokybės požymiai klasifikuojami skirtingose kokybės kategorijose, kurios pagrịstos ryšiu tarp produkto kokybės savybių ir vartotojo pasitenkinimo tomis savybèmis, kuris laikui bėgant kinta. Siekiant vis didesnio vartotojų pasitenkinimo, svarbu tinkamai paskirstyti išteklius, siekiant kokybės. Čia svarbu žinoti, kaip vartotojai vertina kokybės savybes ir nustatyti ryši tarp kiekvienos kokybès savybės bei vartotojo pasitenkinimo.

Šie argumentai leidžia teigti, kad grožio terapijos paslaugų kokybès vertinimas vartotojo požiūriu yra aktualus ir reikalingas.

Grožio terapijos paslaugų kokybės kriterijai. Anglų mokslininkų P. Parasuraman, V. Zeithaml ir L. Berry (1988) sukurtas modelis palygina vartotoju lūkesčius su patirta paslauga. Jame naudojamos penkios kokybès dimensijos (kriterijai): akivaizdumas (apčiuopiamumas, materialinès vertybės); atsakas (reagavimas) - vartotojų poreikių tenkinimo greitis; patikimumas - darbuotojų gebejjimas suteikti paslaugą, atsižvelgiant ị vartotojo lūkesčius; užtikrinimas (tikrumas) - darbuotojų išmanymas ir paslaugumas; empatija (įsijautimas) - individualus dėmesys vartotojams.

Išanalizavus paslaugų kokybės vertinimo veiksnius, skiriami šie pagrindiniai kokybės kriterijai, kuriuos galima pritaikyti grožio terapijos paslaugai, o jų paaiškinimai pateikiami 2 lentelèje. 
2 lentelè. Grožio terapijos paslaugos kokybès kriterijai

\begin{tabular}{|c|c|}
\hline Kokybės kriterijus & Trumpas kriterijaus aprašas \\
\hline Apčiuopiamumas & $\begin{array}{l}\text { Grožio terapijos paslaugų îmonės materialiosios, fizinės priemonės: } \\
\text { patalpos ir įranga, darbuotojų išvaizda, informaciné medžiaga }\end{array}$ \\
\hline Patikimumas & $\begin{array}{l}\text { Grožio terapijos paslaugų teikèjo gebèjimas teikti patikimas paslau- } \\
\text { gas, vykdyti pažadus, suteikti tikslią informaciją }\end{array}$ \\
\hline $\begin{array}{l}\text { Jautrumas } \\
\text { (reagavimas) }\end{array}$ & $\begin{array}{l}\text { Greitas grožio terapijos paslaugos suteikimas ir pagalba vartoto- } \\
\text { jams. Skubus ir efektyvus paslaugos atlikimas, iškilusių problemų } \\
\text { sprendimas, rekomendacijos vartotojams, suderintas kainos ir koky- } \\
\text { bės santykis }\end{array}$ \\
\hline Tikrumas & $\begin{array}{l}\text { Pasitikėjimo ịkvėpimas. Bruožai, kurie suteikia vartotojams pasi- } \\
\text { tikèjimą grožio terapijos paslaugos teikèju (darbuotojų specifinis } \\
\text { paslaugos išmanymas, kompetentingumas, paslaugumas, mandagus } \\
\text { vartotojų aptarnavimas, atsakymai ị visus rūpimus klausimus) }\end{array}$ \\
\hline $\begin{array}{l}\text { Empatija } \\
\text { (ịsijautimas) }\end{array}$ & $\begin{array}{l}\text { Pasirengimas ir gebejjimas suteikti individualias grožio terapijos } \\
\text { paslaugas, individualus dėmesys, rūpestingumas, svetingumas, } \\
\text { geranoriškumas, gebejjimas ịžvelgti vartotojų norus, specialių po- } \\
\text { reikių tenkinimas }\end{array}$ \\
\hline
\end{tabular}

\section{Grožio terapijos paslaugų kokybės vertinimas pasirinktame sektoriniame praktinio mokymo centre}

Kirpimo, grožio terapijos ir susijusių paslaugų sektorinis praktinio mokymo centras (toliau - centras) įkurtas pagal LR S̆MM sektorinių praktinio mokymo centrų programą. Tai moderniausias Baltijos šalyse grožio paslaugų mokymo centras, aprūpintas šiuolaikine ịranga, kuriuo naudojasi profesinis mokymas, aukštosios mokyklos ir darbdaviai. Modernizuotoje mokymo bazèje ịrengti aukščiausio lygio kirpimo, kosmetikos, pedikiūro ir manikiūro, kūno masažo, SPA, makiažo ir permanentinio makiažo, kirpimo ir kiti mokomieji kabinetai, kompiuterizuota mokymo klasè, išvaizdos stiliaus studija, foto ir floristikos studijos, egzaminų centro patalpos. Centre dirba aukštos kvalifikacijos darbuotojai, kurie tobulinosi ịvairiose stažuotèse Lietuvoje ir užsienyje. Teikiamos kirpimo, kosmetikos, SPA, floristikos, ịvaizdžio dizaino ir kitos paslaugos, yra galimybẻ tobulinti kvalifikaciją. Mokymas centre organizuojamas moduliniu principu. Šiame praktinio mokymo centre atlieka praktiką Šv. Ignaco Lojolos kolegijos grožio terapijos studentai.

Siekiant įvertinti teikiamų grožio paslaugų kokybę, 2016 metais kovo - gegužès mènesiais atliktas tyrimas sektoriniame praktinio mokymo centre.

Tyrimo metodai. Sektoriniame praktinio mokymo centre teikiamų paslaugu kokybei ịvertinti pasirinktas kiekybinis tyrimas. Suderinus su centro vadovybe, siekiant nustatyti grožio paslaugų vartotojų požiūrị i jiems teikiamų paslaugų kokybę, atlikta anketinė apklausa. Vertintas vartotojų pasitenkinimas gautomis pas- 
laugomis penkių kokybės kriterijų aspektu: apčiuopiamumo, jautrumo, tikrumo, patikimumo ir empatiškumo. Siekta išsiaiškinti ir lankytojų motyvus, renkantis „X“ centrą. Klausimai sugrupuoti tokia tvarka pagal kokybės kriterijus:

- Apčiuopiamumas: klausimai apie turimas fizines priemones ir įrangą, darbuotojų išvaizdą, reklamą ir informacinę medžiagą, paslaugų ịvairovę, vietą, interjerą, aplinką, švarą ir tvarką.

- Patikimumas: klausimai apie užtikrintą paslaugos atlikimą, atitinkantį vartotojo lūkesčius, personalo elgesį, tiksliai suteiktą informaciją.

- Jautrumas: klausimai apie paslaugų suteikimą laiku ir greitai, iškilusių problemų sprendimą, pagalbą vartotojams, kainos ir kokybės santykį, kliento konsultavimą.

- Tikrumas: klausimai apie pasitikẻjimo įkvėpimą, darbuotojų kompetenciją, mandagų vartotojų aptarnavimą, atsakymus ị visus rūpimus klausimus.

- Empatiškumas: klausimai apie rūpestingumą, svetingumą, geranoriškumą, individualių paslaugų suteikimą vartotojams, gebejjimą įžvelgti vartotojų norus, individualių vartotojų poreikių tenkinimą.

Tyrimui pasirinktas atsitiktinių respondentų elektroninės apklausos metodas. Apklausoje dalyvavo 195 respondentai, iš kurių 93,85 proc. - moterys ir 6,15 proc. - vyrai. Daugiausia apklausoje dalyvavusių respondentu - 20-50 metų amžiaus ir vyresni ( 92,31 proc.). Net 61,54 proc. respondentu - turintys aukštaji išsilavinimą.

Rezultatų aptarimas. Akivaizdu, kad didžioji dalis sektorinio praktinio mokymo centro vartotojų yra aukštajị ar profesinị išsilavinimą turinčios 20-50 metų ir vyresnès moterys. Remiantis šio tyrimo duomenimis, galima teigti, kad dažnas centro lankytojas naudojasi daugiau nei viena paslauga. Didžioji dalis apklaustụjų rinkosi rankų / kojų (30,86 proc.), veido (23,46 proc.), kūno (17,28 proc.) ir plaukų (17,28 proc.) priežiūros paslaugas. Tyrimas atskleidè, kad centre teikiamų paslaugų kaina atitinka jų vertę, taip mano net trys ketvirtadaliai apklaustujų, o paslaugų spektras yra pakankamai platus, kad būtų gerai vertinamas $(95,38$ proc. respondentų nuomonès). Pabrèžtina, kad vartotojai centre teikiamas paslaugas gerai vertina ir daugeliu kitų aspektų, kaip, pvz., paslaugų teikimo punktualumą, naudojamas kosmetikos priemones ir iqrangą $(90,77$ proc. sutinka su teiginiu ir 7,69 proc. iš dalies sutinka). Tai, kad net 92,31 proc. dalyvavusiujų apklausoje yra patenkinti gautomis paslaugomis, leidžia teigti, jog centre teikiamų paslaugų kokybė yra užtikrinta. Paslaugų kokybę užtikrina ir darbuotojų profesionalumas, kuriuo pasitiki didelè respondentų dalis (89,23 proc.). Remiantis tyrimu, centro darbuotojai yra konfidencialūs (96,92 proc.). Respondentų teigimu, darbuotojai geba tinkamai $(87,69$ proc.) ar pakankamai tinkamai $(12,31$ proc.) reaguoti ị vartotojų problemas ir jas greitai spręsti. Net 96,92 proc. apklausos dalyvių nuomone, centro 
darbuotojai skiria dėmesị kiekvienam vartotojui, 92,31 proc. respondentų teigè, kad centro darbuotojai yra mandagūs, 83,08 proc. respondentų manymu, centro darbuotojai domisi inovacijomis. Bemaž visus respondentus tenkina centre naudojamos kosmetikos priemonès: 15,38 proc. patenkinti iš dalies, 84,62 proc. - visiškai patenkinti. Panašiai, tik šiek tiek geriau, respondentai atsiliepia ir apie centre naudojamą įrangą: puikiai ją ịvertino 90,77 proc. Gerai respondentai vertina ir centre dirbančius grožio terapeutus: jų profesionalumu pasitiki net 89,23 proc. apklausos dalyvių, beveik 85 proc. apklaustujų teigimu, darbuotojai geba atsakyti ị vartotojams kylančius klausimus.

Remiantis tyrimo duomenimis, daugiau nei du trečdaliai (70,77 proc.) centro lankytojų yra lojalūs specialistams. Vos 10,77 proc. apklaustujų nesirenka to paties specialisto antrą kartą. 75,38 proc. respondentų teigimu, jiems suteikiama pakankamai informacijos apie procedūras ir jų poveikį, bemaž 80 proc. atvejų jie yra sutinkami ir išlydimi specialisto, 63,08 proc. atvejų specialistas pasiteirauja, kokias priemones vartotojas vartoja namie, net 92,1 proc. atvejų po procedūros respondentų teirautasi apie jų savijautą. Pagal penkių balų vertinimo sistemą, kur 5 - puikiai, o 1 - blogai, paprašyti ịvertinti centro vietą, interjerą, darbuotojų išvaizdą, respondentai geriausiai ịvertino centro švarą ir tvarką, tada - darbuotojų išvaizdą, centro vietą, interjerą ir laukiamąji.

Apklausos rezultatai įrodè, kad centro specialistai - geranoriški, suteikiantys informaciją, gebantys užtikrinti konfidencialumą, tinkamai reaguojantys ị vartotojų problemas, skiriantys pakankamai dėmesio kiekvienam vartotojui, mandagūs, stengiasi pasitikti ir išlydeti kiekvieną klientą, domisi jų savijauta po procedūrų. Remiantis tyrimo rezultatais, centro vartotojams suteikiama pakankamai informacijos apie procedūras ir jų poveikį. Tačiau centro specialistams vertètų labiau stengtis išsiaiškinti, kokias priemones vartotojai vartoja namie ir be išimties kiekvienam centro lankytojui pasiūlyti jam tinkamiausias priemones, taip užtikrinant ilgalaikị teikiamų procedūrų poveikị bei didinant vartotojo pasitikẻjimą specialistais. Pasitikèjimo didinimas ir lojalumo ugdymas - ypač svarbūs, žinant, kad pagrindinès centro klientès - moterys, kurios dažniausia yra lojalios grožio terapeutui. Tai ịrodo ir tyrimo metu gauti duomenys: net 70,77 proc. jų lankosi pas tą pati specialistą. Tačiau toks lojalumas turi ir tam tikros rizikos: dažnas vartotojas, besirenkantis konkretų specialistą, yra lojalus labiau jam nei pačiam centrui, taigi atsiranda galimybė, kad, specialistui pakeitus darbo vietą, vartotojas rinksis kitą grožio terapijos centrą, todèl būtina didinti vartotojo lojalumą centrui, skatinant ji rinktis daugiau nei vienos rūšies paslaugas bei sudarant galimybę patirti ir kitų specialistų profesionalumą. 
Galima drąsiai teigti, kad centro reputacija vertinama teigiamai (98,5 proc.). Ši teiginị patvirtina ir tai, kad net 81,54 proc. apklausos dalyvių jị rekomenduotų savo draugams bei pažistamiems.

Tyrimo rezultatų apibendrinimas. Išanalizavus visus grožio terapijos paslaugų kokybės vertinimo kriterijus, nustatyta, kad sektorinio praktinio mokymo centro vartotojai yra patenkinti teikiamų grožio terapijos paslaugų kokybe:

1. Bendra grožio terapijos paslaugų kokybė yra aukšta. Visos analizuotos paslaugų kokybės dimensijos ịvertintos teigiamai.

2. Informacijos apie paslaugas pateikimas prieinamas ir patrauklus, centro interjeras pritraukia vartotojus, o moderni įranga pritaikyta grožio terapijos paslaugoms teikti ir užtikrina jų atlikimo kokybę. Siekiant pritraukti vartotojus iš užsienio, informacija galètų būti pateikiama ir kitų šalių kalbomis.

3. Centro darbuotojai gerai atlieka savo pareigas: rodo deramą dėmesị kiekvienam vartotojui, aiškinasi jų poreikius ir atsižvelgdami i juos parenka atitinkamas grožio terapijos paslaugas.

4. Centro specialistai grožio terapijos paslaugas suteikia laiku ir be trukdžių, puikiai geba ịveikti problemines situacijas, kad vartotojai liktų patenkinti, pačių darbuotojų elgesys ir aptarnavimas kelia pasitikèjimą. Galima teigti, kad centras vartotojams kelia pasitikejimą.

5. Grožio terapijos paslaugų teikejjai geba paslaugą suteikti profesionaliai, kokybiškai ir patikimai, prieš teikdami paslaugą ịvertinę vartotojo galimybes ir poreikius.

6. Grožio terapijos paslaugas teikiantys darbuotojai nuoširdžiai bendrauja su vartotojais. Jautrumo dimensiją apibūdinantys teiginiai vertinti teigiamai, taip išreikštas respondentų pasitenkinimas suteikta paslauga.

\section{Išvados}

1. Grožio terapijos paslaugos kokybe் - tai grožio terapijos paslaugos savybių visuma, kuri igalina tenkinti šiandieninius arba numanomus vartotojo poreikius.

2. Grožio terapijos paslaugos kokybė gali būti vertinama vadovaujantis tokiais kriterijais kaip apčiuopiamumas, patikimumas, jautrumas, tikrumas, empatiškumas.

3. Išanalizavus anketinès apklausos rezultatus nustatyta, kad sektoriniame praktinio mokymo centre teikiamos paslaugos vartotojų požiūriu yra kokybiškos. Remiantis atlikto tyrimo duomenimis, galima teigti, kad, respondentų nuomone, jie gavo patrauklias, priimtinas, profesionaliai ir koky- 
biškai atliktas paslaugas. Centro reputacija vertinama puikiai, beveik visi apklausos dalyviai jị rekomenduotų savo draugams ir pažistamiems.

\section{Rekomendacijos}

1. Sektorinis praktinio mokymo centras gali būti rekomenduotas kaip praktinio mokymo ir praktikos atlikimo vieta aukštụjų mokyklų grožio terapijos studijų programos studentams.

2. Vadovaujantis tinkamumo reikalavimais įmonėms, siūlančioms praktikos vietas studentams, reikètų atlikti tolesnius tyrimus dèl pasirinkto sektorinio praktinio mokymo centro praktikos organizavimo kokybės (mentorystès, praktikos vertinimo aspektai ir pan.).

Gauta 20170120

Pasirašyta spaudai 20170522

\section{Literatūra}

Bagdonienė, L., Hopenienè, R. (2005). Paslaugu marketingas ir vadyba. Kaunas: Technologija.

The Science of Customer Satisfaction. (2016). ASCI [interaktyvus]. Prieiga internete: http://www.theacsi.org/ about-acsi/the-science-of-customer-satisfaction [žiūrèta 2017-04-07].

Europos vartotoju pasitenkinimo valdymo vadovas. (2010). Lietuvos Respublikos vidaus reikalų ministerija.

Global Beauty Care Products Industry 2012-2017: Trend, Profit, and Forecast Analysis. (2012). Prieiga internete: http://www.researchandmarkets.com/reports/2316299/global_beauty_care_products_industry_20122017 [Žiūrèta 2017-04-10].

Isiūnienė, V., Adomavičienė, G., Mickienė, Ž. (2012). Dirbančiųų grožio terapijos terapijos specialistų kvalifikacijos kèlimo poreikis. Sveikatos mokslai, Nr. 22 (5), p. 188-191.

Jocienė, J., Navikienė, Ž., Valiulienè, J. (2014). Grožio ir grožio terapijos kompetencijų vertinimo metodika. Panevėžys: UAB „Riprosetas“, 63 p.

Kano, N., Nobuhiku, S., Fumio, T., Shinichi, T. (1984). Attractive quality and must-be quality Journal of the Japanese Society for Quality Control (in Japanese), Vol. 14 (2), p. 39-48. ISSN 0386-8230.

Langvinienè, N., Vengrienė, B. (2005). Paslaugu teorija ir praktika. Kaunas: Technologija.

Lietuvos profesiju klasifikatorius. (2012).

Lopaciuk, A., Loboda, M. (2013). Global Beauty Industry Trends in the 21st Century. International Conference „Management, Knowledge and Learning “ [interaktyvus]. Prieiga internete: http://www.toknowpress.net/ ISBN/978-961-6914-02-4/papers/ML13-365.pdf [žiūrèta 2017-01-16].

Palaima, T. (2005). Paslaugų kokybės tyrimo programa: kiekybinių tyrimų galimybès. Marketingas, Nr. 7-8, p. $37-41$.

Vengrienè, B. (2006). Paslaugu vadyba. Vilnius: Vilniaus universiteto leidykla.

Vitkienè, E. (2004). Paslaugu marketingas. Klaipėda: Klaipėdos universitetas.

Lietuvos Respublikos sveikatos apsaugos ministro 2007 m. rugpjūčio 1 d. ịsakymas Nr. V-633 „Dèl Lietuvos higienos normos HN117:2007 „Grožio paslaugų sveikatos saugos reikalavimai“ patvirtinimo“ [interaktyvus]. Prieiga internete: https://www.e-tar.lt/portal/lt/legalAct/TAR.CE03E1D3329D [žiūrèta 2017-04-19]. 
Jūratė Jocienė, Nijolè Deksnienè, Alicija Ramanauskaitė

\title{
BEAUTY THERAPY SERVICES QUALITY ASSESSMENT IN THE SECTORAL PRACTICAL TRAINING CENTER
}

\author{
Jūratė Jocienė, Nijolė Deksnienė, Alicija Ramanauskaitė
}

\section{Summary}

The article analyses the practical aspects of beauty therapy service quality assessment in the sectorial practical training center, describes the beauty therapy service quality and its criteria, presents beauty therapy services quality survey results from a consumer perspective. This article is based on scientific and normative literature analysis on the basis of the quality survey results conducted by the authors. The aim of survey - to evaluate the quality of beauty therapy services in the selected sectorial practical training center from a consumer perspective. The object of research - beauty therapy service quality. The survey tasks: to discuss the concept of beauty therapy services quality; to describe the beauty therapy services quality evaluation criteria and to find out how consumers evaluate the beauty therapy service quality in the selected practical training center.

The theoretical approach is based on the scientific literature and regulatory documents analysis. Analysing beauty therapy service quality trends used the method - systematic and comparative analysis of published scientific literature concepts and conclusions. To identify Beauty Therapy service users' satisfaction with the quality of service established a quantitative survey, which revealed that the quality of beauty therapy services is a whole of beauty therapy services features, which makes it possible to meet today or implied user needs. Beauty therapy services quality can be evaluated according to criteria such as Tangibility, Reliability, Responsiveness, Assurance, and Empathy. The analysis of the questionnaire results showed that sectorial practical training center providing services to consumers in terms of the quality. According to the study, it can be said that the respondents think they got an attractive, reasonable, professional and high-quality services rendered. Sectorial Center's reputation is well-regarded and nearly all respondents would recommend it to their friends and acquaintances.

In the article is analysed how consumers evaluate the quality of beauty therapy services. The aim of the article - to evaluate the quality of beauty therapy services in sectorial practical training center on consumers' viewpoint. The aim moves out the following objectives: 1 . Reveal the beauty therapy service quality concept. 2. To describe the beauty therapy services quality evaluation criteria. 3. Find out how customers evaluate the beauty care service quality in practical training center. The methods used: analysis of scientific literature, analysis of documents, sum- 
mary, synthesis, questionnaire, statistical analysis of the data. According to the Lithuanian and foreign scientific literature theoretical and practical aspects are considered on beauty therapy service quality, in order to analyse and identify itenhancing items. The article disclosures of beauty therapy quality concept and its application on beauty therapy service quality assessment. The practical part of the survey in sectorial practical training center $\mathrm{X}$ assess emphasis how users evaluate beauty therapy service quality on consumers'viewpoint. Conclusions:

1. Beauty Therapy service quality can be understood as a beauty therapy services set of a characteristic that enables to meet or implied user needs.

2. Beauty Therapy service quality can be evaluated according to certain criteria, such as tangibility, reliability, sensitivity, authenticity, empathy.

3. An analysis of the questionnaire survey results found that in the center the beauty therapy services are offered of high quality on consumers' viewpoint. According to this conclusion, sectorial practical training center can be recommended as a practical training place for beauty therapy study program students. 
